\title{
Income inequality, life expectancy and cause-specific mortality in 43 European countries, 1987-2008: a fixed effects study
}

\author{
Yannan $\mathrm{Hu}^{1}$ • Frank J. van Lenthe ${ }^{1}$. \\ Johan P. Mackenbach ${ }^{1}$
}

Received: 17 March 2015/Accepted: 30 June 2015/Published online: 16 July 2015

(c) The Author(s) 2015. This article is published with open access at Springerlink.com

\begin{abstract}
Whether income inequality is related to population health is still open to debate. We aimed to critically assess the relationship between income inequality and mortality in 43 European countries using comparable data between 1987 and 2008, controlling for time-invariant and time-variant country-level confounding factors. Annual data on income inequality, expressed as Gini index based on net household income, were extracted from the Standardizing the World Income Inequality Database. Data on life expectancy at birth and age-standardized mortality by cause of death were obtained from the Human Lifetable Database and the World Health Organization European Health for All Database. Data on infant mortality were obtained from the United Nations World Population Prospects Database. The relationships between income inequality and mortality indicators were studied using country fixed effects models, adjusted for time trends and country characteristics. Significant associations between income inequality and many mortality indicators were found in pooled cross-sectional regressions, indicating higher mortality in countries with larger income inequalities. Once the country fixed effects were added, all associations between income inequality and mortality indicators became insignificant, except for mortality from external causes and homicide among men, and cancers among women. The significant results for homicide and
\end{abstract}

Electronic supplementary material The online version of this article (doi:10.1007/s10654-015-0066-x) contains supplementary material, which is available to authorized users.

Yannan $\mathrm{Hu}$

y.hu@erasmusmc.nl; hyn153599@gmail.com

1 Department of Public Health, Erasmus University Medical Centre, PO Box 2040, 3000 CA Rotterdam, The Netherlands cancers disappeared after further adjustment for indicators of democracy, education, transition to national independence, armed conflicts, and economic freedom. Crosssectional associations between income inequality and mortality seem to reflect the confounding effects of other country characteristics. In a European context, national levels of income inequality do not have an independent effect on mortality.

Keywords Europe $\cdot$ Mortality $\cdot$ Life expectancy $\cdot$ Causes of death · Income inequality - Fixed effects models

\section{Introduction}

Whether income inequality harms population health is still open to debate. Since Wilkinson [1] postulated the hypothesis that income inequality was not simply a summary of the balance of income between the rich and poor, but is a health risk in its own right [2], a wide array of studies, including multilevel studies within countries and cross-country ecological studies examined the link between income distribution and population health $[3,4]$. However, no agreement has yet been reached because of discrepancies between the results of different studies.

International comparative studies linking income inequality to mortality suffer from limited comparability of the income inequality measures between countries and over time [5-7]. The Luxembourg Income Study (LIS) [8], regarded as the "gold standard", is the first choice for many studies $[1,5,9,10]$ because of its high quality and comparability. It covers, however, only a limited set of country-year observations, which may be the reason why many studies using this database performed a cross-sectional analysis. The Deininger and Squire database (1996) 
is often chosen as an alternative source $[6,11,12]$ and provides more observations, but at a substantial loss of comparability. The World Income Inequality Database (WIID) covers the most comprehensive set of income inequality statistics. It incorporates several data sources, and enables researchers to maximize comparability by choosing data based on the criteria of comparability, but potentially leads to a risk of not piecing together the information in a meaningful way $[13,14]$. The more recently developed Standardizing the World Income Inequality Database (SWIID) maximizes comparability for the broadest available set of country-year observations, and as such is better suited than other income inequality datasets for cross-country comparative research [14].

With some exceptions [9, 12], cross-sectional studies found significantly worse population health at higher levels of income inequality [1, 15-17]. However, these associations sometimes diminished after adjustment for observed country characteristics $[3,4,6,11,18]$, suggesting there is a substantial risk of confounding. Fixed effect models, which require longitudinal data, are able to adjust for unobservable time-invariant confounding variables, by linking changes in income inequality to changes in health. Studies using fixed effects models to study the effect of income inequality on population health often reported insignificant results $[6,7,11,19-21]$. However, these studies pooled men and women together $[6,7,10,11,19$, $22,23]$, used relatively old data $[6,11,19]$, restricted the outcome to infant mortality [21], or ignored some potential time-variant confounders $[6,10,19,20,23,24]$. Only few studies investigated disease-specific outcomes, which would help to interpret findings on the basis of existing knowledge on determinants of population health and could point towards potential pathways through which income inequality may harm population health [7, 11, 19]. Studies specifically assessing the association between income inequality and mortality in a European context, which would be important for policy makers in Europe, are also limited in number $[25,26]$.

Using the SWIID data, we therefore aimed to refine and extend previous studies by critically investigating the relationships between income inequality and a set of disease-specific mortality indicators by gender in fixed effects models for 43 European countries over the period 1987-2008 [21].

\section{Data and methods}

\section{Data}

For income inequality, we made use of a new dataset called Standardizing the World Income Inequality Database
(SWIID). Using the Gini index as measure, SWIID took version 2.0c of the WIID [27] as the starting-point and standardized it based on the inequality observations from the LIS [8]. Standardizing procedures were applied to account for differences in (a) population coverage (e.g. whether data cover all or nearly all of a country's population), (b) income reference units (e.g. household per capita, household adult equivalent, or household without adjustment of number of people), and (c) the definition of income (e.g. net income, gross income, expenditures or unidentified income). Finally, missing observations were imputed based on proximate years using a custom multiple-imputation algorithm [14]. In this study, we extracted information on the Gini index based on net household income (post-tax post-transfer) from SWIID version 4.0 covering 43 European countries with 879 country-year observations.

Data on life expectancy at birth and age-standardized mortality by cause of death at all ages (further referred to as "mortality indicators") were extracted from the Human Lifetable Database (www.lifetable.de) and the World Health Organization European Health for All Database (http://data.euro.who.int/hfadb/). Data on infant mortality, measured as infant deaths per 1000 live births, were obtained from the United Nations World Population Prospects database (http://esa.un.org/wpp/Excel-Data/mortal ity.htm). All mortality rates are log-transformed for normalization. ICD-code numbers are reported in a previous paper [28].

A key variable potentially confounding the relationship between income inequality and mortality, and for which the majority of existing studies controlled, is national income, which was measured by gross domestic product (GDP) per head of population (in $\$ 1000$ s, extracted from a dataset compiled by Maddison http://www.ggdc.net/MAD DISON/oriindex.htm). Besides GDP, a number of other potential confounders were added where appropriate, including indicators of democracy (the Policy2 index ranging from "strongly democratic $(+10)$ " to "strongly autocratic (-10)", extracted from the Quality of Government dataset, http://www.qog.pol.gu.se/data/), average years of schooling (extracted from the Barro-Lee Educational Attainment dataset, http://www.barrolee.com/, made into annual data by linear interpolation), transition to national independence ( 0 for no transition, 1 for the year of independence and the three subsequent years), armed conflict (ranging from 0 for "no conflict" to 3 for "more than 1000 battle deaths per year", constructed using data on conflict location extracted from the Quality of Government dataset, http://www.qog.pol.gu.se/data/), and economic freedom (ranging from 0 to 10 , extracted from the Economic Freedom of the World 2011 dataset and imputed some missing data for earlier periods using the 2002 dataset update, http://www.freetheworld.com/). 
Indicators of democracy, education and economic freedom were chosen because they represent changes in the underlying political, social and financial conditions prevailing in each country. Indicators of transition to national independence and armed conflicts were chosen to account for the disruption of governance structures and political changes in Central and Eastern Europe, and some Mediterranean and Western Balkan countries during the study-period. All these variables have been documented to affect population health in Europe [28] and potentially correlate with but may not be seen as causally resulting from income inequality [29-31].

\section{Analytical approach}

To align with previous studies, we first explored the pooled cross-sectional relation between income inequality and mortality. We adjusted analyses for year dummies and GDP per capita, and subsequently included more confounding variables. Robust standard errors were used to account for heteroskedasticity [32].

The model can be written as:

healthoutcome $_{i j}=\alpha+\beta_{1}$ Gini $_{i j}+\beta_{2} \ln g d p_{i j}+T_{j}+\gamma C_{i j}$

where health outcome $e_{i j}$ is the life expectancy or logarithmic form of the age-adjusted mortality rates for country $i$ in year $\mathrm{j}$; $\alpha$ is a constant; Gini $_{\mathrm{ij}}$ represents the Gini index; $\operatorname{lngdp_{ij}}$ is the logarithmic form of GDP per head, accounting for the potential non-linear relationship between national income and health; $T_{j}$ is a vector of year dummies controlling the shared time trend in mortality during the study period; $\mathrm{C}_{\mathrm{ij}}$ represents other potential timevariant confounders including indicators of democracy, years of schooling, independence, armed conflict and economic freedom, which were added subsequently.

As the next step, we applied fixed effects models, which allowed to control for unobserved time-invariant country heterogeneity, such as cultural, social, historical, geographic and other conditions that remained relatively constant within the study period. The results of the fixed effects models can be interpreted as the relationship between annual changes in income inequality and annual changes in health outcomes. Clustered sandwich estimators were used to allow for within-country correlation between error terms [32].

The model can be written as:

$$
\begin{aligned}
\text { healthoutcome }_{i j}= & \alpha+\beta_{1} \text { Gini }_{i j}+\beta_{2} \ln g d p_{i j}+X_{i}+T_{j} \\
& +\gamma C_{i j}
\end{aligned}
$$

where $X_{i}$ is a vector of country fixed effects.

In the online supplementary material, supplementary analyses checking robustness of the results are reported, which include (a) models allowing a different linear time trend and different effects of the country characteristics for the former Soviet countries (Supplementary Table 2); (b) models allowing country-specific linear time trends by including the interaction terms between country dummies and year (Supplementary Table 2); (c) analyses restricted to high-income countries within Europe (Supplementary Table 3); (d) analyses using the Gini index based on gross instead of net household income (Supplementary Table 4); (e) analyses sequentially replacing contemporaneous Gini indexes by indexes up to 10 years before the mortality outcomes ("lagged terms") (Supplementary Table 5); (f) analyses using the Gini index from the LIS instead of the SWIID (Supplementary Table 6).

All regression analyses were performed in Stata 13.1.

\section{Results}

Table 1 reports descriptive information on the Gini index, life expectancy and infant mortality in the period between 1987 and 2008 for each country (other outcomes are described in the Supplementary Table 1). In some countries, information on the Gini index only became available in more recent periods (e.g. Iceland, Cyprus, Albania, Bosnia Hercegovina, Malta, Montenegro and Serbia). The Gini index ranges from 15.77 (Slovakia in 1989) to 47.94 (Azerbaijan in 1997). The mean Gini index over the whole period was generally lower in the Nordic region, and higher in Britain and Ireland, and in countries of the former Soviet Union. Higher standard deviations of the Gini index reflect higher within-country variations over time, which particularly occurred in countries of the former Soviet Union and the Western Balkans. The mean life expectancy was lowest in former Soviet countries, followed by countries of the Western Balkans and Central and Eastern Europe. They were relatively similar to each other in the other four European regions. Infant mortality was highest in former Soviet countries, followed by countries of the Western Balkans and Central and Eastern Europe. Life expectancy of women was higher than life expectancy of men in all countries.

Figure 1 shows the trends of the Gini index experienced by the seven European regions over this period. Britain and Ireland and the Mediterranean countries maintained a high level of income inequality over time, while Nordic countries maintained a relatively low level of income inequality. Most regions experienced an increasing trend of income inequality between 1987 and 2008, with a substantial increase in former Soviet countries in the early 1990's.

Table 2 shows the results of linear regression analyses linking income inequality to life expectancy or causespecific mortality by gender when all country-year observations were pooled together. Income inequality was significantly and negatively related to life expectancy for both 


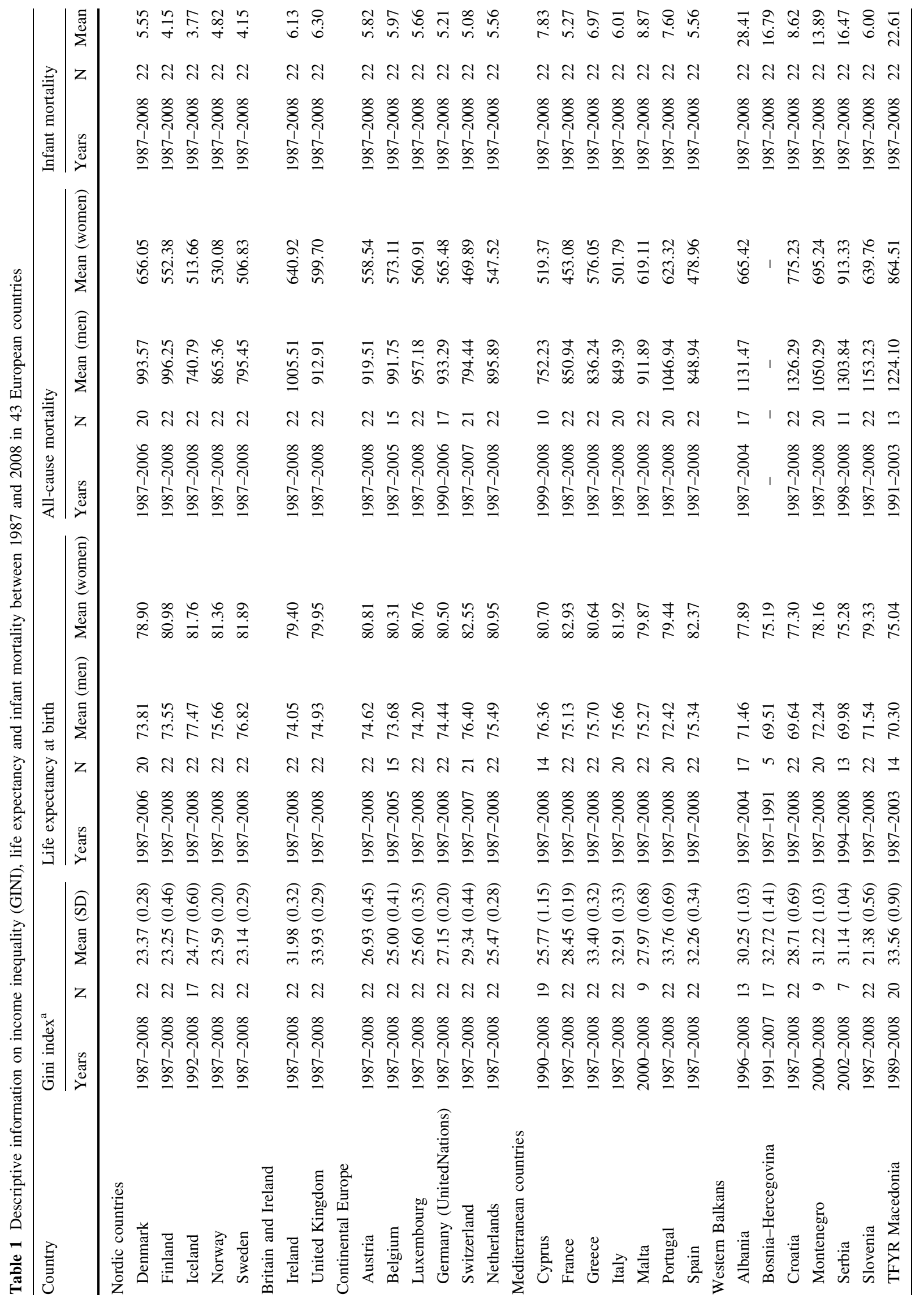




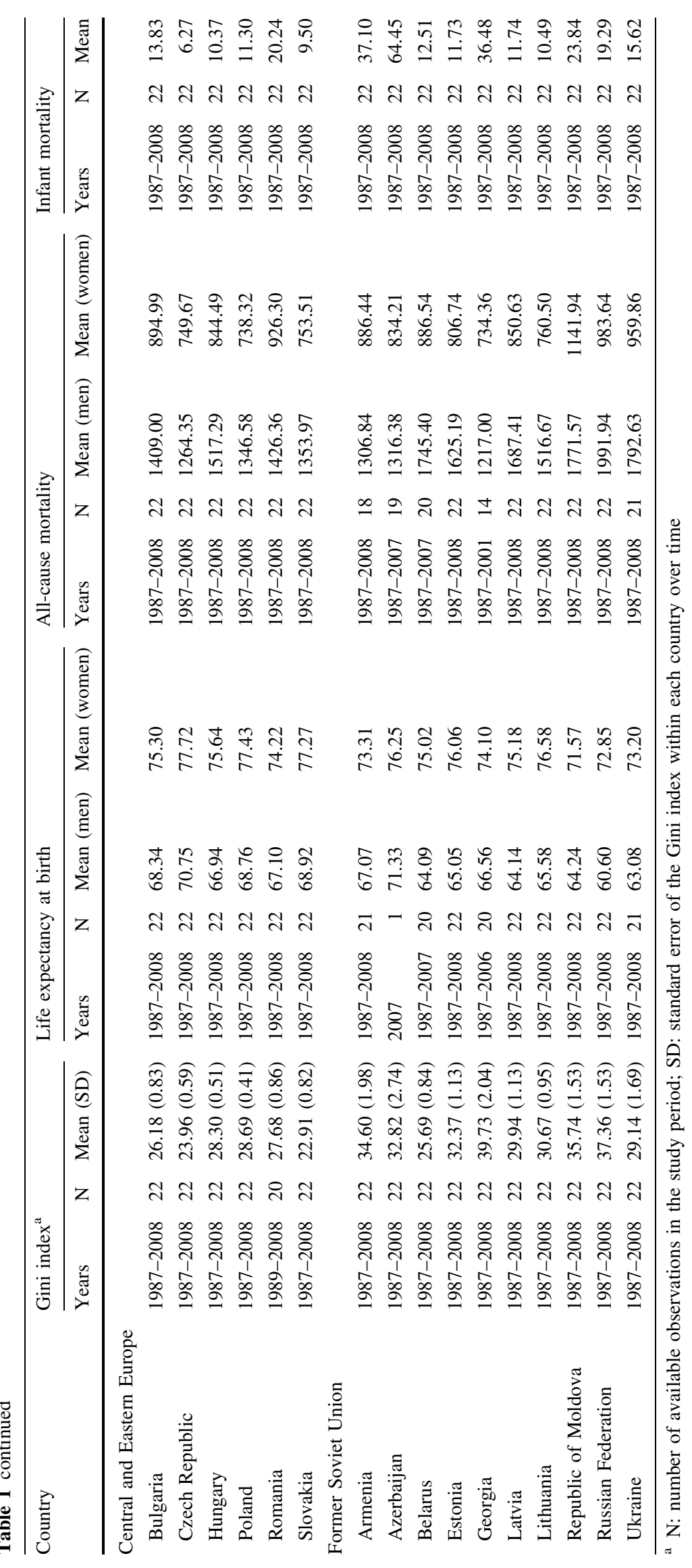




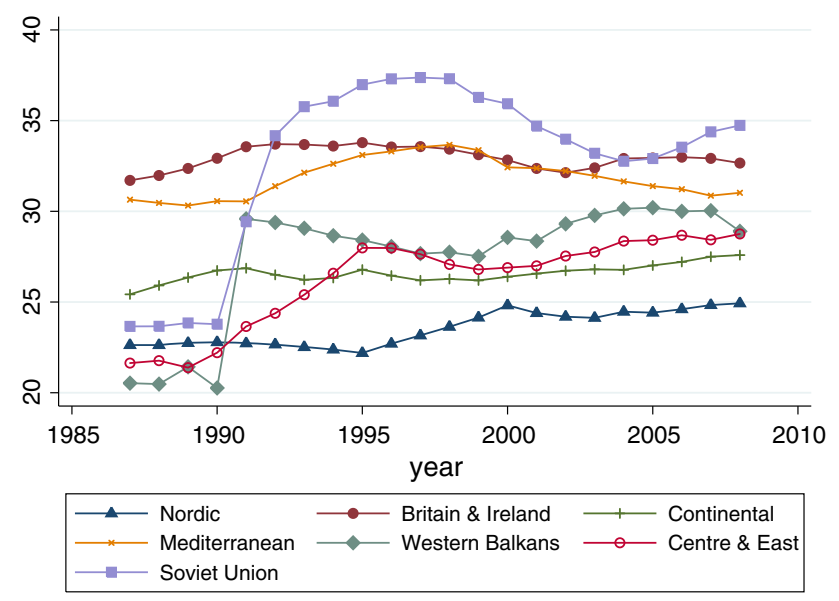

Fig. 1 Trends in income inequality (mean GINI) for 7 European regions (41 countries), 1987-2008 ( $\mathrm{N}=840)$, the SWIID database. After 1990, UK experienced an increase of income inequality and Ireland experienced a decrease of income inequality. The line for Britain and Ireland is an average trend of these two countries. 41 European countries were included in this graph, where Cyprus and TFYR Macedonia were excluded. This is because the Gini index of Cyprus was much lower than that of other Mediterranean countries and it was available from 1990. The inclusion of Cyprus would cause a sudden decrease of the Mediterranean average Gini index at the point of 1990. Similarly, the Gini index of TFYR Macedonia was much higher than that of other Western Balkan countries and it was available from 1989. The inclusion of TFYR Macedonia would cause a sudden increase of the Western Balkan average Gini index at the point of 1989

men and women, indicating shorter life expectancies with larger income inequalities. This negative association was stronger for men than for women, and remained significant after additional adjustments for indicators of education, democracy, independence, armed conflicts and economic freedom. For cause-specific mortality, adjusted for GDP and time, income inequality was positively related to mortality from cerebrovascular disease (among women), all infectious disease, signs, symptoms and ill-defined conditions, and homicide (among men), and income inequality was also negatively related to some causes of mortality, such as all cancers and suicide. After further adjustment for indicators of education, democracy, independence, armed conflicts and economic freedom, positive associations with income inequality were found for almost all causes of mortality (except deaths from lung cancer among women, breast cancer, chronic liver diseases and suicide). The inverse association between income inequality and infant mortality was significant and remained significant after adjustment for the potential confounding variables.

Table 3 presents the results from fixed effects models linking changes in income inequality to changes in life expectancy or cause-specific mortality. All associations between income inequality and mortality indicators became insignificant, except for death from external causes and homicide among men, and all cancers among women. The significant results of homicide and all cancers disappeared after further adjustment of more country characteristics. In further analyses (Supplementary Table 2), the positive relation between income inequality and death from external causes appeared not robust to variations in model specifications.

Essentially similar results were obtained in supplementary analyses for robustness checks: allowing a different time trend and interactive effects of the country characteristics for the former Soviet countries, allowing countryspecific linear time trends, restricting the analyses to highincome countries, and using gross income Gini index. Moreover, we also introduced up to 10 year lags between the income inequality and life expectancy or infant mortality into the fixed effects models. None of the lagged terms of Gini index was significant. Simultaneously controlling all preceding income inequalities [33] gave essentially similar results (available upon request). Similar analyses were conducted using interpolated LIS data, which also have good quality but much less country-year observations. Again, statistically significant associations between income inequality and mortality were rare. Additionally controlling for the unemployment rate did not change our main findings (results not shown). These checks indicate that our main findings are robust against different model specifications, sample changes, using a Gini index based on gross household income and using another dataset for income inequality.

\section{Discussion}

\section{Summary of main findings}

Significant associations between income inequality and many mortality indicators were found in pooled crosssectional regressions, indicating higher mortality in countries with larger income inequalities. However, once the country fixed effects were added, all associations between income inequality and mortality indicators became insignificant, except for all external causes and homicide among men, and all cancers among women. The significant results of homicide and all cancers disappeared after further adjustment for indicators of democracy, average years of schooling, transition to national independence, armed conflicts, and economic freedom.

\section{Study limitations}

To identify the link between income inequality and mortality, we adjusted for an array of country characteristics. In 
Table 2 Linear regression coefficients of GINI from pooled cross-sectional analyses linking income inequality and population health measured by life expectancy and mortality, pooled 43 European countries 1987-2008

\begin{tabular}{|c|c|c|c|c|}
\hline \multirow[t]{2}{*}{ Outcomes } & \multicolumn{2}{|l|}{ Men } & \multicolumn{2}{|l|}{ Women } \\
\hline & Model $1^{\mathrm{a}}$ & Model $2^{b}$ & Model 1 & Model 2 \\
\hline Life expectancy & $\begin{array}{l}-0.0820 \\
(-0.130,-0.034)\end{array}$ & $\begin{array}{l}-0.2590 \\
(-0.317,-0.201)\end{array}$ & $\begin{array}{l}-0.0371 \\
(-0.065,-0.010)\end{array}$ & $\begin{array}{l}-0.0901 \\
(-0.122,-0.058)\end{array}$ \\
\hline All causes & $\begin{array}{l}0.0001 \\
(-0.003,0.004)\end{array}$ & $\begin{array}{l}0.0128 \\
(0.009,0.017)\end{array}$ & $\begin{array}{l}-0.0014 \\
(-0.004,0.001)\end{array}$ & $\begin{array}{l}0.0056 \\
(0.003,0.008)\end{array}$ \\
\hline All circulatory disease & $\begin{array}{l}-0.0030 \\
(-0.007,0.001)\end{array}$ & $\begin{array}{l}0.0109 \\
(0.005,0.016)\end{array}$ & $\begin{array}{l}-0.0020 \\
(-0.006,0.002)\end{array}$ & $\begin{array}{l}0.0110 \\
(0.006,0.016)\end{array}$ \\
\hline Ischemic heart disease & $\begin{array}{l}0.0022 \\
(-0.005,0.009)\end{array}$ & $\begin{array}{l}0.0156 \\
(0.007,0.024)\end{array}$ & $\begin{array}{l}0.0006 \\
(-0.007,0.009)\end{array}$ & $\begin{array}{l}0.0119 \\
(0.003,0.021)\end{array}$ \\
\hline Cerebrovascular disease & $\begin{array}{l}0.0056 \\
(-0.001,0.012)\end{array}$ & $\begin{array}{l}0.0203 \\
(0.013,0.027)\end{array}$ & $\begin{array}{l}0.0098 \\
(0.004,0.016)\end{array}$ & $\begin{array}{l}0.0235 \\
(0.017,0.030)\end{array}$ \\
\hline All cancers & $\begin{array}{l}-0.0066 \\
(-0.010,-0.003)\end{array}$ & $\begin{array}{l}0.0045 \\
(0.002,0.007)\end{array}$ & $\begin{array}{l}-0.0055 \\
(-0.010,-0.001)\end{array}$ & $\begin{array}{l}0.0102 \\
(0.007,0.014)\end{array}$ \\
\hline Cancer of lung & $\begin{array}{l}-0.0058 \\
(-0.012,0.00002)\end{array}$ & $\begin{array}{l}0.0148 \\
(0.010,0.020)\end{array}$ & $\begin{array}{l}-0.0197 \\
(-0.026,-0.013)\end{array}$ & $\begin{array}{l}-0.0213 \\
(-0.030,-0.012)\end{array}$ \\
\hline Cancer of breast & & & $\begin{array}{l}0.0015 \\
(-0.003,0.006)\end{array}$ & $\begin{array}{l}0.0032 \\
(-0.001,0.007)\end{array}$ \\
\hline All infectious disease & $\begin{array}{l}0.0349 \\
(0.026,0.043)\end{array}$ & $\begin{array}{l}0.0463 \\
(0.036,0.057)\end{array}$ & $\begin{array}{l}0.0205 \\
(0.014,0.027)\end{array}$ & $\begin{array}{l}0.0130 \\
(0.006,0.020)\end{array}$ \\
\hline Chronic liver disease and cirrhosis & $\begin{array}{l}0.0003 \\
(-0.013,0.014)\end{array}$ & $\begin{array}{l}0.0006 \\
(-0.021,0.022)\end{array}$ & $\begin{array}{l}0.0119 \\
(-0.001,0.025)\end{array}$ & $\begin{array}{l}0.0034 \\
(-0.014,0.021)\end{array}$ \\
\hline All external causes & $\begin{array}{l}-0.0017 \\
(-0.011,0.008)\end{array}$ & $\begin{array}{l}0.0301 \\
(0.020,0.041)\end{array}$ & $\begin{array}{l}-0.0086 \\
(-0.017,-0.001)\end{array}$ & $\begin{array}{l}0.0162 \\
(0.008,0.024)\end{array}$ \\
\hline Motor vehicle accidents & $\begin{array}{l}0.0053 \\
(-0.004,0.015)\end{array}$ & $\begin{array}{l}0.0381 \\
(0.029,0.048)\end{array}$ & $\begin{array}{l}0.0010 \\
(-0.008,0.010)\end{array}$ & $\begin{array}{l}0.0293 \\
(0.020,0.038)\end{array}$ \\
\hline Suicide & $\begin{array}{l}-0.0375 \\
(-0.053,-0.022)\end{array}$ & $\begin{array}{l}0.0070 \\
(-0.006,0.020)\end{array}$ & $\begin{array}{l}-0.0443 \\
(-0.057,-0.031)\end{array}$ & $\begin{array}{l}-0.0139 \\
(-0.026,-0.002)\end{array}$ \\
\hline Signs, symptoms and ill-defined & $\begin{array}{l}0.0249 \\
(0.008,0.042)\end{array}$ & $\begin{array}{l}0.0455 \\
(0.21,0.070)\end{array}$ & $\begin{array}{l}0.0234 \\
(0.004,0.042)\end{array}$ & $\begin{array}{l}0.0377 \\
(0.011,0.065)\end{array}$ \\
\hline Homicide & $\begin{array}{l}0.0175 \\
(0.001,0.034) \\
\text { Infant }\end{array}$ & $\begin{array}{l}0.0584 \\
(0.039,0.078)\end{array}$ & $\begin{array}{l}-0.0089 \\
(-0.024,0.006)\end{array}$ & $\begin{array}{l}0.0256 \\
(0.008,0.043)\end{array}$ \\
\hline Infant mortality & $\begin{array}{l}0.0216 \\
(0.015,0.028)\end{array}$ & $\begin{array}{l}0.0166 \\
(0.012,0.021)\end{array}$ & & \\
\hline
\end{tabular}

Bold values indicate significant results at the $95 \%$ confidence level

${ }^{a}$ Model 1 includes Gini index (95\% confidence interval in parentheses, based on robust standard errors), year dummies and log (gdp)

b Model 2 additionally adds democracy index, education, independence, armed conflict and economic freedom

order to be confounding variables, these factors should be related to both income inequality and mortality. To the extent however, that these indicators result from income inequality, and therefore should be considered as mediating variables, we may have over-controlled the analyses and thereby removed part of the association between income inequality on mortality. Whether the country characteristic should be seen as a confounder or mediator is not easy to determine, especially for education [34]. On the one hand, investing in education could be a strategy to reduce income inequality within a country [30], making it a potential confounder. On the other hand, high levels of income inequality and the associated underinvestment in public resources might in the long run lead to lower levels of education [35], which makes it a potential mediator. However, most associations between income inequality and mortality indicators were insignificant in the fixed effects models even without controlling for education and 
Table 3 Linear regression coefficients of GINI from fixed effects models linking income inequality and population health measured by life expectancy and mortality, 43 European countries 1987-2008

\begin{tabular}{|c|c|c|c|c|}
\hline \multirow[t]{2}{*}{ Outcomes } & \multicolumn{2}{|l|}{ Men } & \multicolumn{2}{|l|}{ Women } \\
\hline & Model $1^{\mathrm{a}}$ & Model $2^{b}$ & Model 1 & Model 2 \\
\hline Life expectancy & $\begin{array}{l}-0.0754 \\
(-0.178,0.027)\end{array}$ & $\begin{array}{l}-0.0811 \\
(-0.174,0.012)\end{array}$ & $\begin{array}{l}-0.0049 \\
(-0.071,0.061)\end{array}$ & $\begin{array}{l}-0.0361 \\
(-0.077,0.005)\end{array}$ \\
\hline All causes & $\begin{array}{l}0.0054 \\
(-0.0005,0.011)\end{array}$ & $\begin{array}{l}0.0044 \\
(-0.001,0.010)\end{array}$ & $\begin{array}{l}0.00002 \\
(-0.005,0.005)\end{array}$ & $\begin{array}{l}0.0020 \\
(-0.002,0.006)\end{array}$ \\
\hline All circulatory diseases & $\begin{array}{l}0.0063 \\
(-0.003,0.015)\end{array}$ & $\begin{array}{l}0.0022 \\
(-0.005,0.010)\end{array}$ & $\begin{array}{l}0.0022 \\
(-0.006,0.011)\end{array}$ & $\begin{array}{l}0.0010 \\
(-0.004,0.006)\end{array}$ \\
\hline Ischemic heart disease & $\begin{array}{l}0.0060 \\
(-0.003,0.015)\end{array}$ & $\begin{array}{l}-0.0009 \\
(-0.011,0.009)\end{array}$ & $\begin{array}{l}0.0019 \\
(-0.007,0.011)\end{array}$ & $\begin{array}{l}-0.0044 \\
(-0.015,0.006)\end{array}$ \\
\hline Cerebrovascular disease & $\begin{array}{l}0.0061 \\
(-0.004,0.017)\end{array}$ & $\begin{array}{l}0.0036 \\
(-0.005,0.013)\end{array}$ & $\begin{array}{l}0.0029 \\
(-0.008,0.014)\end{array}$ & $\begin{array}{l}0.0034 \\
(-0.005,0.011)\end{array}$ \\
\hline All cancers & $\begin{array}{l}0.0035 \\
(-0.001,0.008)\end{array}$ & $\begin{array}{l}0.0032 \\
(-0.0001,0.007)\end{array}$ & $\begin{array}{l}0.0051 \\
(0.0001,0.010)\end{array}$ & $\begin{array}{l}0.0036 \\
(-0.001,0.009)\end{array}$ \\
\hline Cancer of lung & $\begin{array}{l}0.0030 \\
(-0.002,0.008)\end{array}$ & $\begin{array}{l}0.0018 \\
(-0.006,0.009)\end{array}$ & $\begin{array}{l}-0.0068 \\
(-0.016,0.003)\end{array}$ & $\begin{array}{l}-0.0052 \\
(-0.016,0.005)\end{array}$ \\
\hline Cancer of breast & & & $\begin{array}{l}0.0061 \\
(-0.003,0.015)\end{array}$ & $\begin{array}{l}0.0035 \\
(-0.003,0.010)\end{array}$ \\
\hline All infectious diseases & $\begin{array}{l}0.0068 \\
(-0.008,0.022)\end{array}$ & $\begin{array}{l}0.0235 \\
(-0.009,0.056)\end{array}$ & $\begin{array}{l}0.00005 \\
(-0.015,0.015)\end{array}$ & $\begin{array}{l}0.0126 \\
(-0.013,0.038)\end{array}$ \\
\hline Chronic liver disease and cirrhosis & $\begin{array}{l}0.0153 \\
(-0.004,0.035)\end{array}$ & $\begin{array}{l}0.0086 \\
(-0.015,0.032)\end{array}$ & $\begin{array}{l}0.0153 \\
(-0.007,0.037)\end{array}$ & $\begin{array}{l}0.0015 \\
(-0.021,0.024)\end{array}$ \\
\hline All external causes & $\begin{array}{l}0.0143 \\
(0.0002,0.028)\end{array}$ & $\begin{array}{l}0.0143 \\
(0.001,0.028)\end{array}$ & $\begin{array}{l}0.0078 \\
(-0.007,0.023)\end{array}$ & $\begin{array}{l}0.0158 \\
(0.001,0.031)\end{array}$ \\
\hline Motor vehicle accidents & $\begin{array}{l}0.0091 \\
(-0.007,0.025)\end{array}$ & $\begin{array}{l}0.0048 \\
(-0.009,0.018)\end{array}$ & $\begin{array}{l}0.0109 \\
(-0.004,0.026)\end{array}$ & $\begin{array}{l}0.0054 \\
(-0.009,0.020)\end{array}$ \\
\hline Suicide & $\begin{array}{l}0.0051 \\
(-0.007,0.017)\end{array}$ & $\begin{array}{l}0.0104 \\
(-0.0003,0.021)\end{array}$ & $\begin{array}{l}-0.0009 \\
(-0.015,0.013)\end{array}$ & $\begin{array}{l}0.0127 \\
(-0.001,0.027)\end{array}$ \\
\hline Signs, symptoms and ill-defined & $\begin{array}{l}0.0219 \\
(-0.011,0.055)\end{array}$ & $\begin{array}{l}0.0338 \\
(-0.003,0.070)\end{array}$ & $\begin{array}{l}0.0078 \\
(-0.029,0.045)\end{array}$ & $\begin{array}{l}0.0290 \\
(-0.007,0.065)\end{array}$ \\
\hline Homicide & $\begin{array}{l}0.0285 \\
(0.008,0.049) \\
\text { Infant }\end{array}$ & $\begin{array}{l}0.0171 \\
(-0.002,0.036)\end{array}$ & $\begin{array}{l}0.0147 \\
(-0.004,0.033)\end{array}$ & $\begin{array}{l}0.0066 \\
(-0.009,0.022)\end{array}$ \\
\hline Infant mortality & $\begin{array}{l}-0.0023 \\
(-0.007,0.002)\end{array}$ & $\begin{array}{l}-0.0498 \\
(-0.130,0.031)\end{array}$ & & \\
\hline
\end{tabular}

Bold values indicate significant results at the $95 \%$ confidence level

${ }^{a}$ Model 1 includes Gini index (95\% confidence interval in parentheses, based on clustered standard errors), year dummies, log (gdp) and country fixed effects

b Model 2 additionally adds democracy index, education, independence, armed conflict and economic freedom

other country time-variant characteristics. Thus, the general conclusions are not threatened by the potential problem of "over-controlling".

In the main analyses, we related annual changes in income inequality to simultaneous annual changes in mortality. We also investigated the effects of income inequality in a specific year on mortality up to 10 years later, which produced similar results. This approach may be insufficient to fully capture the cumulative impact of a history of large income inequalities on mortality $[21,22,36]$. Future research, using data over even longer time-periods than available in our study, are necessary to explore the effects of long-term exposure to income inequality.

Our analysis was limited to European countries. This reduced the potential for confounding as country-level 
confounding variables can be expected to be more similar in Europe than in a global context. It also produced results that are relevant for policy makers in European countries, who are likely to be more concerned with the effect of income inequality as observed within the range of variation prevailing in a European context, than with the more extreme values of income inequality observed elsewhere in the world. However, it is important to note that our results cannot be generalized beyond this smaller range of variation, and that analyses including countries outside Europe with larger increases in income inequality over time may lead to different conclusions.

\section{Interpretation}

Our findings are in line with previous studies that found negative cross-sectional associations between income inequality and population health [1, 15, 16], and with some existing studies using fixed effects models where no significant effects were found $[6,19,21]$. We further strengthened the evidence however, because our results were obtained in a study in which we focused on a large array of European countries over a relatively long period of time, used better data on income inequalities and a set of disease-specific mortality indicators, considered a larger set of potential confounding variables, and used a country fixed effects approach. The only significant result in our fixed effects analysis, after adjustment for country characteristics, was the association between income inequality and external causes mortality. This cause of death group is strongly related to individual socioeconomic status [37, 38]. However, the results for all external causes mortality were not robust to variations in model specifications in further analyses (Supplementary Table 2).

Differences between results from pooled cross-sectional analyses and fixed effects models indicate that the observed association between income inequality and mortality is likely to result from confounding, and that income inequality as such is not a driving force of poor population health. We can only speculate which country characteristics might be responsible for the disappearance of the effect, and suspect that these are historical, social or cultural factors that are associated with both the hierarchical nature of societies, as indicated by income inequality, and the health of their populations. Unfortunately, many of these factors are not available in international databases. Further research is necessary to find appropriate measures for the relevant country characteristics and test their effects on the association between income inequality and mortality.

One underlying factor determining both income inequality and mortality could be social and health policies that vary across countries and are persistent over time. For example, poverty reduction policies such as minimum wage, disability allowances and return to work programs can reduce income inequality and simultaneously improve average population health by improving health of the poorest part of the population. Besides these, health care programs such as smoking cessation strategies, maternal education programs and cancer screening may also play roles since they tend to cluster in countries with strong redistribution policies, although without having a direct impact on income inequality [21]. The implementation of all these policies has varied between European countries [39], which could have produced a "spurious" association between income inequality and mortality. Other responsible factors could be some cultural and historical elements of a country, e.g. egalitarianism (importance of transcending self-interest and promoting the welfare of others), power distance (extent to which the less powerful accept that power is distributed unequally) and ethnic heterogeneity, which are potentially important determinants of population health [40,41], and at the same time could be related to income inequality $[42,43]$. The disappearance of the association between income inequality and health when moving to fixed effects models could be the result of controlling for these country heterogeneities.

It has been noted that the most consistent evidence for an adverse effect of income inequality on population health derives from within-country differences in the United States or some other countries with comparable or even larger income inequalities [3, 36]. The studies from countries having more equal income distribution outside of Europe, e.g. Canada, Australia and Japan, often produced insignificant findings [44, 45]. Therefore, one possible explanation for not finding significant relationships in our study is that most European countries in our sample are more egalitarian than the United States. It has been suggested that there is a "threshold effect", implying the existence of a threshold of income inequality above which adverse impacts on health begin to emerge [46]. However, this appears to only partly explain our findings, since restricting the analysis to the 18 countries with a mean Gini index larger than 30 (a potential threshold value suggested in the literature [46] ) still produced insignificant results (results not shown). Another possible explanation for not finding significant relationships is that income inequality may be less strongly associated with the social distribution of major risk factors in Europe. For example, the delay of the epidemiologic transition and the more egalitarian social distribution of healthy "Mediterranean diets" in southern Europe make lower income less a risk factor for cardiovascular disease mortality in these countries [3, 47, 48]. Meanwhile, the well-developed welfare system in Europe, especially in some northern and continental European countries, may help to buffer the adverse effect on 
mortality of being poor [49]. A deeper exploration of why income inequality does not have more effect in Europe is needed.

\section{Conclusions}

Within Europe, cross-sectional associations between income inequality and mortality probably result from confounding. Fixed effect models which remove time-invariant country heterogeneity suggest that there is no statistically significant relation between income inequality and population health measured by life expectancy and cause-specific mortality in European countries between 1987 and 2008. Although reducing income inequality may be important for creating equality of opportunity and for the reduction of health inequalities, it has a limited role for reducing average mortality in Europe.

Acknowledgments Yannan $\mathrm{Hu}$ is supported by the project DEMETRIQ (Developing Methodologies to Reduce Inequalities in the Determinants of Health, Grant agreement No. 278511), which received funding from the European Union under the FP7 Health programme.

\section{Compliance with Ethical Standards}

Conflict of Interest The authors declare that they have no conflict of interest.

Ethical approval This article does not contain any studies with animals performed by any of the authors. Ethics approval is not required for this paper. We had no information on individual human subjects. For this article, we used aggregated income inequality data and mortality data at the national level, which have been published online.

Informed consent Informed consent is not needed for this paper since we had no information on individual human subjects.

Open Access This article is distributed under the terms of the Creative Commons Attribution 4.0 International License (http://crea tivecommons.org/licenses/by/4.0/), which permits unrestricted use, distribution, and reproduction in any medium, provided you give appropriate credit to the original author(s) and the source, provide a link to the Creative Commons license, and indicate if changes were made.

\section{References}

1. Wilkinson RG. Income distribution and life expectancy. BMJ. 1992;304(6820):165-8.

2. Deaton A. Commentary: the convoluted story of international studies of inequality and health. Int J Epidemiol. 2002;31(3): $546-9$

3. Lynch JW, et al. Is income inequality a determinant of population health? Part 1. A systematic review. Milbank Q. 2004;82(1): 5-99.
4. Wilkinson RG, Pickett KE. Income inequality and population health: a review and explanation of the evidence. Soc Sci Med. 2006;62(7):1768-84.

5. Judge K, Mulligan JA, Benzeval M. Income inequality and population health. Soc Sci Med. 1998;46(4-5):567-79.

6. Beckfield J. Does income inequality harm health? New crossnational evidence. J Health Soc Behav. 2004;45(3):231-48.

7. Leigh A, Jencks C. Inequality and mortality: long-run evidence from a panel of countries. J Health Econ. 2007;26(1):1-24.

8. LIS, Luxembourg Income Study (LIS) Data Access: http://www. lisdatacenter.org/data-access/ (2008). Accessed 22 Apr 2014.

9. Lynch JW, et al. Income inequality, the psychosocial environment, and health: comparisons of wealthy nations. Lancet. 2001;358(9277):194-200.

10. Leigh A, Jencks C, Smeeding TM. Health and economic inequality. In: Salverda W, Nolan B, Smeeding TM, editors. The oxford handbook of economic inequality. Oxford: Oxford University Press; 2009.

11. Mellor JM, Milyo J. Reexamining the evidence of an ecological association between income inequality and health. J Health Polit Policy Law. 2001;26(3):487-522.

12. Gravelle H, Wildman J, Sutton M. Income, income inequality and health: what can we learn from aggregate data? Soc Sci Med. 2002;54(4):577-89.

13. Atkinson $\mathrm{AB}$, Brandolini A. Promise and pitfalls in the use of 'secondary' data-sets: income inequality in OECD countries as a case study. J Econ Lit. 2001;39(3):771-99.

14. Solt F. Standardizing the world income inequality database. Soc Sci Q. 2009;90(2):231-42.

15. De Vogli R, et al. Has the relation between income inequality and life expectancy disappeared? Evidence from Italy and top industrialised countries. J Epidemiol Community Health. 2005;59 (2):158-62.

16. Rodgers GB. Income and inequality as determinants of mortality: an international cross-section analysis. Popul Stud. 1979;33: $343-51$.

17. Ram R. Further examination of the cross-country association between income inequality and population health. Soc Sci Med. 2006;62(3):779-91.

18. Macinko JA, et al. Income inequality and health: a critical review of the literature. Med Care Res Rev. 2003;60(4):407-52.

19. Babones SJ. Income inequality and population health: correlation and causality. Soc Sci Med. 2008;66(7):1614-26.

20. Shkolnikov VM, et al. Losses of expected lifetime in the United States and other developed countries: methods and empirical analyses. Demography. 2011;48(1):211-39.

21. Avendano M. Correlation or causation? Income inequality and infant mortality in fixed effects models in the period 1960-2008 in 34 OECD countries. Soc Sci Med. 2012;75(4): 754-60.

22. Clarkwest A. Neo-materialist theory and the temporal relationship between income inequality and longevity change. Soc Sci Med. 2008;66(9):1871-81.

23. Pop IA, van Ingen E, van Oorschot W. Inequality, wealth and health: is decreasing income inequality the key to create healthier societies? Soc Indic Res. 2013;113(3):1025-43.

24. Torre R, Myrskyla M. Income inequality and population health: an analysis of panel data for 21 developed countries, 1975-2006. Popul Stud (Camb). 2014;68(1):1-13.

25. Bobak M, et al. Societal characteristics and health in the former communist countries of Central and Eastern Europe and the former Soviet Union: a multilevel analysis. J Epidemiol Community Health. 2007;61(11):990-6.

26. Zagorski $\mathrm{K}$, et al. Does national income inequality affect individuals' quality of life in Europe? Inequality, happiness, finances, and health. Soc Indic Res. 2014;117(3):1089-110. 
27. UNU-WIDER: World Income Inequality Database, Version 2.0c. http://www.wider.unu.edu/research/Database/en_GB/database/ (2008). Accessed 17 Mar 2015.

28. Mackenbach JP, Hu Y, Looman CW. Democratization and life expectancy in Europe, 1960-2008. Soc Sci Med. 2013;93:16675.

29. Reuveny R, Li Q. Economic openness, democracy, and income inequality-an empirical analysis. Comp Polit Stud. 2003;36(5): 575-601.

30. Sylwester K. Can education expenditures reduce income inequality? Econ Educ Rev. 2002;21(1):43-52.

31. Carter JR. An empirical note on economic freedom and income inequality. Public Choice. 2007;130(1-2):163-77.

32. Wooldridge JM. Econometric analysis of cross section and panel data. 2nd ed. Cambridge: MIT Press; 2010.

33. Zheng H. Do people die from income inequality of a decade ago? Soc Sci Med. 2012;75(1):36-45.

34. Mackenbach JP. Income inequality and population health. BMJ. 2002;324(7328):1-2.

35. Lynch JW, et al. Income inequality and mortality: importance to health of individual income, psychosocial environment, or material conditions. BMJ. 2000;320(7243):1200-4.

36. Kawachi I, Subramanian SV. Income inequality. In: Berkman LF, Kawachi I, Glymour MM, editors. Social epidemiology. USA: Oxford University Press; 2014. p. 126-51.

37. Middelkoop BJ, et al. Urban cause-specific socioeconomic mortality differences. Which causes of death contribute most? Int J Epidemiol. 2001;30(2):240-7.

38. Leinsalu M, et al. Educational inequalities in mortality in four Eastern European countries: divergence in trends during the postcommunist transition from 1990 to 2000. Int $\mathrm{J}$ Epidemiol. 2009;38(2):512-25.

39. Mackenbach JP, McKee M. Successes and failures of health policy in Europe: four decades of diverging trends and converging challenges. Buckingham: Open University Press; 2013.
40. Alesina A, Baqir R, Easterly W. Public goods and ethnic divisions. Q J Econ. 1999;114(4):1243-84.

41. Mackenbach JP. Cultural values and population health: a quantitative analysis of variations in cultural values, health behaviours and health outcomes among 42 European countries. Health Place. 2014;28:116-32.

42. Hofstede G. Dimensionlizing cultures: the Hofstede model in context. Online Read Psychol Cult. 2011. http://scholarworks.gvsu. edu/cgi/viewcontent.cgi?article $=1014 \&$ context=orpc. Accessed 01 Dec 2014.

43. Kraal K, Roosblad J, Wrench J. Equal opportunities and ethnic inequality in European labour markets: discrimination, gender and policies of diversity. Amsterdam: Amsterdam University Press; 2009.

44. Ross NA, et al. Relation between income inequality and mortality in Canada and in the United States: cross sectional assessment using census data and vital statistics. BMJ. 2000;320(7239): 898-902.

45. Ross NA, et al. Metropolitan income inequality and working-age mortality: a cross-sectional analysis using comparable data from five countries. J Urban Health. 2005;82(1):101-10.

46. Kondo $\mathrm{N}$, et al. Income inequality, mortality, and self rated health: meta-analysis of multilevel studies. BMJ. 2009;339: b4471.

47. Kulhanova I, et al. Why does Spain have smaller inequalities in mortality? An exploration of potential explanations. Eur J Pub Health. 2014;24(3):370-7.

48. Mackenbach JP, et al. Socioeconomic inequalities in health in 22 European countries. N Engl J Med. 2008;358(23):2468-81.

49. Zambon A, et al. Do welfare regimes mediate the effect of socioeconomic position on health in adolescence? A cross-national comparison in Europe, North America and Israel. Int $\mathbf{J}$ Health Serv. 2006;36(2):309-29. 